\title{
Organochlorine Pesticide Residues in Sediments and Waters from Cocoa Producing Areas of Ondo State, Southwestern Nigeria
}

\author{
Aderonke Adetutu Okoya, ${ }^{1}$ Aderemi Okunola Ogunfowokan, ${ }^{2}$ \\ Olabode Idowu Asubiojo, ${ }^{2}$ and Nelson Torto ${ }^{3}$ \\ ${ }^{1}$ Institute of Ecology and Environmental Studies, Obafemi Awolowo University, Ile-Ife, Nigeria \\ ${ }^{2}$ Department of Chemistry, Obafemi Awolowo University, Ile-Ife, Nigeria \\ ${ }^{3}$ Department of Chemistry, Rhodes University, Grahamstown 6140, South Africa \\ Correspondence should be addressed to Aderonke Adetutu Okoya; ronkeokoya@yahoo.com
}

Received 10 January 2013; Accepted 5 February 2013

Academic Editors: D. Lin, C. Martius, and D. van Tuinen

Copyright (C) 2013 Aderonke Adetutu Okoya et al. This is an open access article distributed under the Creative Commons Attribution License, which permits unrestricted use, distribution, and reproduction in any medium, provided the original work is properly cited.

\begin{abstract}
This study investigated levels of organochlorine pesticide (OCP) residues in water and sediment samples from eleven rivers serving as drinking water sources and receiving runoff from nearby cocoa plantations in Ondo State, Nigeria. Twenty-two composite samples of surface water and sediments $(0-3 \mathrm{~cm})$ were collected randomly using grab technique and replicated thrice per season. The efficiency of the two techniques [supercritical fluid extraction (SFE) and liquid/liquid extraction (LLE)] was evaluated with percentage analyte recoveries $98.17 \pm 0.03$ to $134.72 \pm 0.02$ for SFE and $84.82 \pm 3.32$ to $1102.83 \pm 3.17$ for LLE. Determination of OCPs by gas chromatography with electron capture detection gave higher concentrations for sediments compared to the equivalent water samples. The commonly occurring pesticide residues in the sediments were (range, $\mu \mathrm{g} \mathrm{g}^{-1}$ ) cis-chlordane $0.03-6.99 ; \alpha$ endosulfan 0.03-6.99; p, $\mathrm{p}^{\prime}$-DDE 0.08-19.04; and dieldrin 0.01-7.62; in the sediments and dieldrin (not detected-1.51 $\mu \mathrm{g} \mathrm{L}{ }^{-1}$ ) in water samples, during the dry season. OCP levels were significantly $(P<0.05)$ higher in dry season than wet season among the rivers. The study concluded that most of the rivers in cocoa growing areas were contaminated with OCPs associated with agricultural activities.
\end{abstract}

\section{Introduction}

In spite of the benefits (especially with respect to food production and health management) derived from the use of pesticides, the environmental consequences of the widespread use, handling, and disposal methods of pesticides are of great concern $[1,2]$. It had been reported that the constraints during acquisition [3] and application of pesticides in the humid forest zones could lead to the risky handling of obsolete pesticides which represents a threat to health and environment. This is because their toxicity has led to the deterioration of human health [4] especially with respect to cancer, neurological damage, and abnormal immune system including the foetus and foetus reproductive system [58] as well as fish kills, honey bee poisonings, and the contamination of livestock products [9].

The most commonly used pesticides are the organochlorine pesticides and they are considered to be responsible for the various environmental consequences. The largest regional example of pesticide contamination and human health is perhaps that of the Aral sea-region in Asia [10]. Human health effects of pesticides are caused by inhalation and ingestion through skin contact, handling of pesticide products, breathing of dust or spray and pesticides consumed on/in food, water and aquatic organisms. In view of their toxicity to some plants and insects and persistence in the 
TABLE 1: Percentage recoveries, retention times, and response factors of the pesticide standard mixture.

\begin{tabular}{lcccc}
\hline Standards & LLE & \% Recovery & Retention time (min) & Response factor \\
\hline HCB & $97.79 \pm 1.13$ & $103.14 \pm 0.05$ & 8.31 & 0.41 \\
$\alpha$ BHC & $90.27 \pm 8.34$ & $99.59 \pm 0.03$ & 8.58 & 0.48 \\
$\beta$ BHC & $93.30 \pm 2.09$ & $99.57 \pm 0.01$ & 9.74 & 0.56 \\
$\gamma$ BHC & $98.58 \pm 3.15$ & $130.41 \pm 16.01$ & 9.52 & 0.54 \\
Heptachlor & $99.46 \pm 1.22$ & $99.91 \pm 0.02$ & 10.52 & 11.51 \\
Aldrin & $96.61 \pm 1.48$ & $99.85 \pm 0.02$ & 14.07 & 1.07 \\
Trans-Chlordane & $94.02 \pm 1.79$ & $134.72 \pm 0.02$ & 14.59 & 1.10 \\
Cis-Chlordane & $96.01 \pm 1.96$ & $100.29 \pm 0.01$ & 14.59 & 15.41 \\
$\alpha$-endosulfan & $96.01 \pm 1.85$ & $100.29 \pm 0.01$ & 15.83 & 0.60 \\
p,p ${ }^{\prime}$-DDE & $94.48 \pm 1.11$ & $99.86 \pm 0.02$ & 16.38 & 0.60 \\
Dieldrin & $87.93 \pm 2.33$ & $98.17 \pm 0.03$ & 17.16 & 0.68 \\
o,p'-DDD & $102.83 \pm 3.17$ & $124.95 \pm 0.02$ & 17.72 & 1.03 \\
Endrin & $91.40 \pm 3.53$ & $107.90 \pm 0.04$ & 18.12 & 0.81 \\
p,p'-DDD & $91.68 \pm 1.54$ & $115.10 \pm 0.03$ & 1.08 \\
$\beta$-endosulfan & $84.82 \pm 3.32$ & $115.35 \pm 0.01$ & 0.80 \\
p,p'-DDT & $90.79 \pm 4.56$ & $115.89 \pm 0.02$ & 22.96 & 1.05 \\
Methoxychlor (I. S.) & & & & 0.86 \\
\hline
\end{tabular}

environment, many synthetic organochlorine compounds have found extensive use as pesticides $[1,11]$. Pesticides usage is indeed responsible for the current ability of the developed countries to produce and harvest large amount of food crops on relatively small amount of land with a relatively small input of human labour.

One major problem of cocoa growing is presented by diseases and pests [12-14]. Large scale spraying of pesticides against these diseases has been employed by most farmers. A lot of effort has been channeled by environmental protection agencies and organizations in developed countries towards regulation of organochlorine pesticides use in order to prevent their concentrations from exceeding permissible levels, particularly in our food supply. Pesticides contamination was also reported in areas where citric crops are predominant by Pitarch et al. [15]. Five watersheds relevant to the sustainability of the area were also monitored [15-17] for pesticides in Salmonid-bearing streams under the auspices of Washington State Departments of Ecology and Agriculture. Residues of organochlorine pesticides were investigated in the water and surface sediments from the lower reaches of the Yangtze River to evaluate their pollution and potential risks. The study reported that there was no obvious trend of declining DDT concentrations in the sediments from the river [18].

The need for pesticide regulation and enforcement of such with respect to pest management, safeguarding users and consumers' health, and the protection of the environment is a task that must be achieved. In Nigeria, apart from the national guidelines and standards for industrial effluents, gaseous emission and hazardous wastes [19], the National Agency for Food and Drugs Administration and Control (NAFDAC) also made the Pesticide Registration Regulation, 1996 under Decree 15 of the Federal Republic of Nigeria, 1993.
The law made application for the registration of pesticides compulsory with prescribed guidelines. The regulation specified that "No pesticide shall be manufactured, formulated, imported, advertised, sold or distributed in Nigeria unless it has been registered in accordance with the provisions of these Regulations" [20]. In spite of the laudable provisions, lack of enforcement of the law by the regulatory agency still makes the containment of the risk associated with the use of pesticides an elusive task in Nigeria. The marketing of pesticides in Nigeria is very much unorganized and lacks proper legislative control. This has made it difficult to determine the various market sizes, types, and shares of pesticides in use. Hence there is no dependable official statistics on the type and amount of pesticides imported into the country [21]. However, environmental pollution control is just beginning to receive the desired attention in Nigeria. An important component of this is in the reliable information on the levels of key pollutants in different media and settings in the country. Akinnifesi et al. [22] investigated the physicchemical characteristics of soils in the main cocoa producing area of Ondo state and found that fungicide residues caused a significant increase in soil acidity, organic matter, and copper concentrations. The general occurrence, persistence, and consequences in the environment of OCPs and the fact that it is inevitable, that persistent organic pollutants (POPs) contaminated sites will continue to represent an environmental issue for contemporary and future generations to address [23] make it important to determine their levels in some areas of likely predominance.

Ondo State is a major cocoa producing area in Nigeria. In addition to supplying much-needed raw materials for some local industries, cocoa export is an important source of foreign exchange earnings for the country. In Nigeria, there 
TABLE 2: Sampling sites and their geographical position.

\begin{tabular}{|c|c|c|c|}
\hline$S / N$ & Sample & GPS location of sampling point & Local name of study unit \\
\hline 1 & $\mathrm{R}_{1} \mathrm{~S}_{1}$ & $\begin{array}{r}07^{\circ} 10^{\prime} 27.9^{\prime \prime} \mathrm{N} \\
004^{\circ} 51^{\prime} 54.22^{\prime} \mathrm{E}\end{array}$ & Agoo river at Ile-Oluji \\
\hline 2 & $\mathrm{R}_{2} \mathrm{~S}_{2}$ & $\begin{array}{l}07^{\circ} 18^{\prime} 36.6^{\prime \prime} \mathrm{N} \\
005^{\circ} 39^{\prime} 55.3^{\prime \prime} \mathrm{E}\end{array}$ & Ose river at Ose \\
\hline 3 & $\mathrm{R}_{3} \mathrm{~S}_{3}$ & $\begin{array}{l}07^{\circ} 16^{\prime} 27.1^{\prime \prime} \mathrm{N} \\
005^{\circ} 9^{\prime} 56.9^{\prime \prime} \mathrm{E}\end{array}$ & Ala river at Akure \\
\hline 4 & $\mathrm{R}_{4} \mathrm{~S}_{4}$ & $\begin{array}{l}07^{\circ} 6^{\prime} 39.8^{\prime \prime} \mathrm{N} \\
004^{\circ} 49^{\prime} 26.7^{\prime \prime} \mathrm{E}\end{array}$ & Luwa river at Ondo \\
\hline 5 & $\mathrm{R}_{5} \mathrm{~S}_{5}$ & $\begin{array}{l}07^{\circ} 15^{\prime} 35.8^{\prime \prime} \mathrm{N} \\
005^{\circ} 22^{\prime} 46.4^{\prime} \mathrm{E}\end{array}$ & Ogbese river at Ogbese \\
\hline 6 & $\mathrm{R}_{6} \mathrm{~S}_{6}$ & $\begin{array}{l}07^{\circ} 10^{\prime} 17.4^{\prime \prime} \mathrm{N} \\
004^{\circ} 43^{\prime} 5.5^{\prime} \mathrm{E}\end{array}$ & Oni river at Ifetedo/Oke-Igbo \\
\hline 7 & $\mathrm{R}_{7} \mathrm{~S}_{7}$ & $\begin{array}{l}07^{\circ} 13^{\prime} 56^{\prime \prime} \mathrm{N} \\
005^{\circ} 3^{\prime} 54.1 \mathrm{E}\end{array}$ & Aponmu river at Aponmu \\
\hline 8 & $\mathrm{R}_{8} \mathrm{~S}_{8}$ & $\begin{array}{l}07^{\circ} 13^{\prime} 56^{\prime \prime} \mathrm{N} \\
004^{\circ} 15^{\prime} 00^{\prime \prime} \mathrm{E}\end{array}$ & Osun river at Osogbo \\
\hline 9 & $\mathrm{R}_{9} \mathrm{~S}_{9}$ & $\begin{array}{l}07^{\circ} 13^{\prime} 56^{\prime \prime} \mathrm{N} \\
004^{\circ} 30^{\prime} 00^{\prime \prime} \mathrm{E}\end{array}$ & Opa river at Ile-Ife \\
\hline 10 & $\mathrm{R}_{10} \mathrm{~S}_{10}$ & $\begin{array}{l}07^{\circ} 24^{\prime} 10.9^{\prime \prime} \mathrm{N} \\
005^{\circ} 00^{\prime} 49.5^{\prime \prime} \mathrm{E}\end{array}$ & Owena-Osun river at Owena-Ijesa \\
\hline 11 & $\mathrm{R}_{11} \mathrm{~S}_{11}$ & $\begin{array}{c}07^{\circ} 11^{\prime} 52.2^{\prime \prime} \mathrm{N} \\
005^{\circ} 01^{\prime} 14.6^{\prime \prime} \mathrm{E}\end{array}$ & Owena-Ondo river in Ondo \\
\hline
\end{tabular}

seems to be paucity of data on the monitoring of pesticide residues in the country. Cocoa farmers in Nigeria have a long history of pesticide usage on their farms. Cocoa, being a plantation crop, had been subjected to large volume of insecticides annually since 1957 especially for the control of the brown cacao mirid, Sahlbergella singularis Haglund $[20,21]$. Hence, this study is designed to provide information on the levels of OCPs in the sediments and surface water from rivers that flow through the main cocoa-producing areas of Ondo State of Nigeria, where the cocoa farmers have employed pesticide spraying operations on their cocoa farms.

\section{Materials and Methods}

\subsection{Sample Collection, Preservation, Preparation, and Storage}

2.1.1. Sampling Sites. Sediment and water samples of rivers in some cocoa producing areas of Ondo State, Nigeria were collected as shown in Figure 1. These rivers included Oluwa, Owena-Osun, Owena-Ondo, Ose, Ogbese, Ala, Agoo, Aponmu, Oni, Opa and Osun. Opa, and Osun rivers were sampled where there was no cocoa plantation to serve as controls.

2.1.2. Water samples. Grab sampling technique was used to collect six core surface water samples randomly which was homogenized to form a composite sample $(2.5 \mathrm{~L})$ per river. Each was replicated thrice per season to give a total of 66 samples. Concentrated sulphuric acid $(5.0 \mathrm{~mL})$ was added to each of the samples immediately after the collection to prevent microbial degradation of samples. The samples were kept cool during transportation to the laboratory and then stored at $4^{\circ} \mathrm{C}$ in a refrigerator, until analysed.

2.1.3. Sediment Samples. Sediment samples were collected from the $0-3 \mathrm{~cm}$ depth from the same site as water samples, wrapped up in aluminium foil and then put in a polyethylene bag. Samples were kept cool during transportation to the laboratory. At the laboratory, they were freeze-dried prior to sample preparation and analysis. Sediment samples were later thawed and air-dried at ambient temperature. The composite dried sediment samples were processed through $2.0 \mathrm{~mm}$ stainless steel sieve. The less than $63 \mu \mathrm{m}$ soil samples were prepared using the $63 \mu \mathrm{m}$ stainless steel sieve prior to analysis.

\subsection{Extraction of OCPs from the Sediment and Surface Water} Samples. The sample cell was packed with some glass-wool, after which $3 \mathrm{~g}$ sediment samples fortified with pesticides standards in the concentration range of $1-50 \mathrm{ppm}$ and with $500 \mu \mathrm{L}$ modifier (methanol/acetone mixture ratio $2: 3$ ) spiked onto the sediment was introduced and glass-wool was added to fill the cell completely. The cell was pressurized to $300 \mathrm{bar}$ at $60^{\circ} \mathrm{C}$ with $\mathrm{SC}-\mathrm{CO}_{2}$ (density $=0.872 \mathrm{~g} / \mathrm{mL}$ ).

The pressure was maintained for $20 \mathrm{~min}$ (static extraction) and dynamic extraction was carried out for another $30 \mathrm{~min}$. The extract was collected into a glass tube containing $5 \mathrm{~mL}$ acetone and then concentrated to about $2 \mathrm{~mL}$ on a vacuum rotary evaporator. 


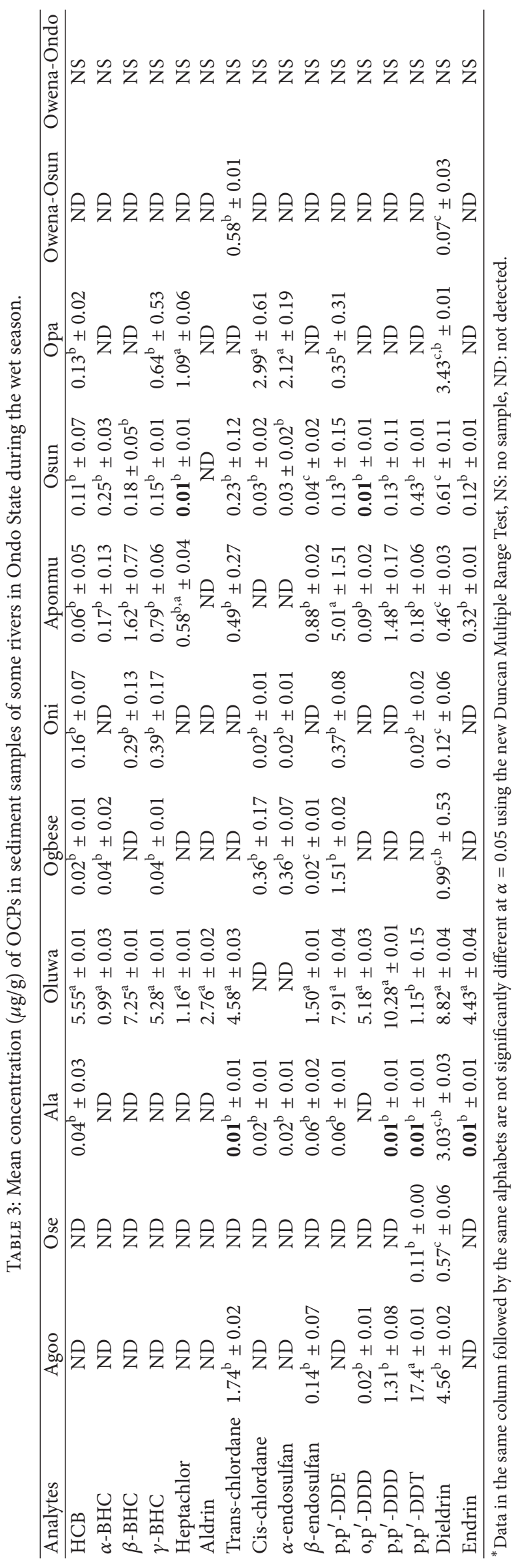




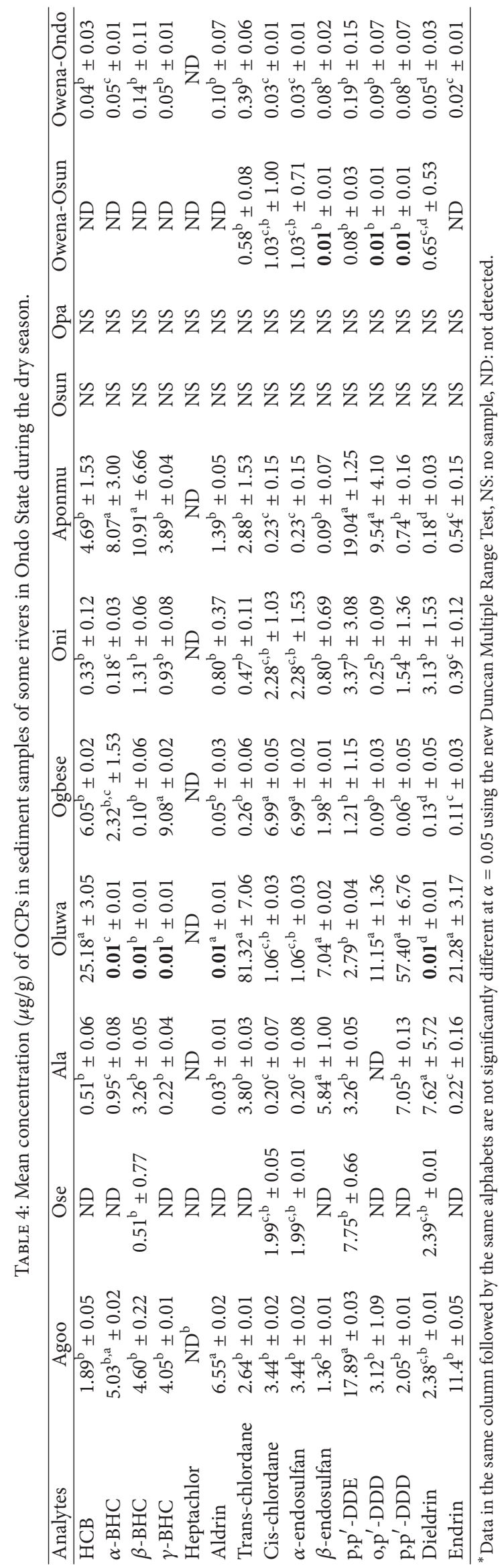




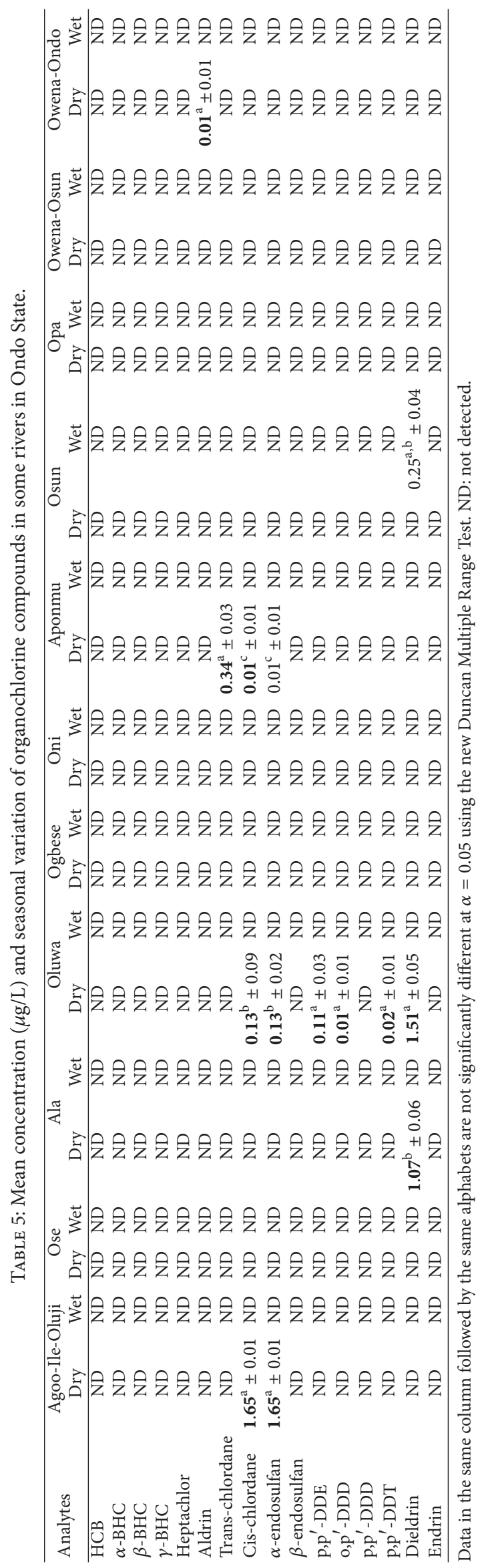




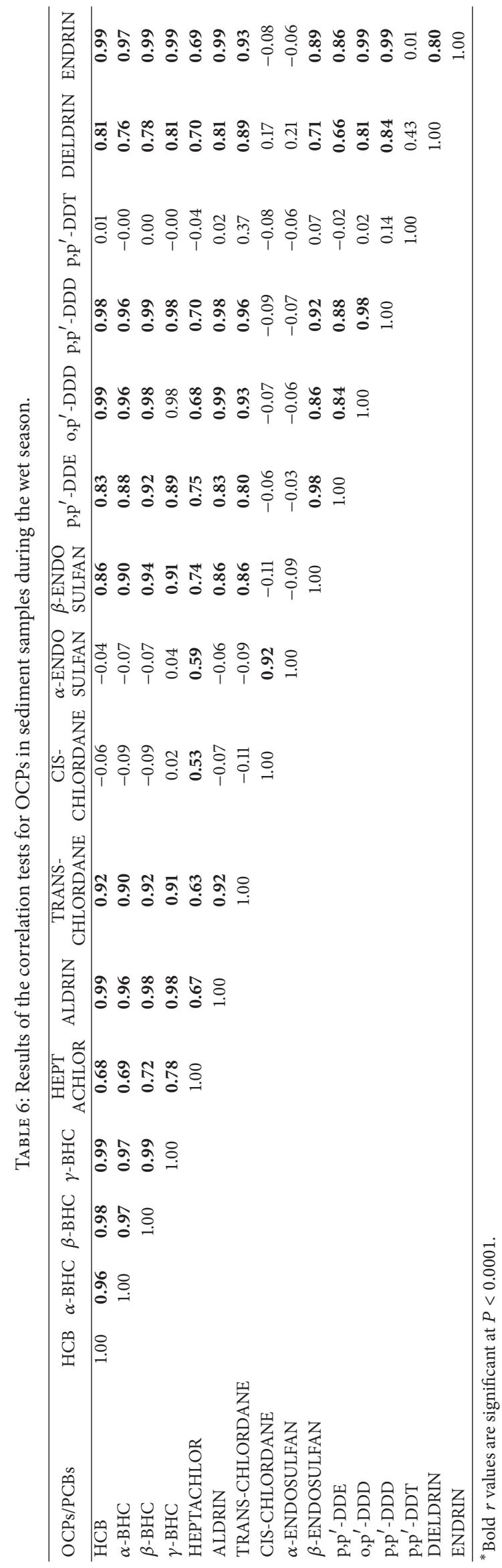




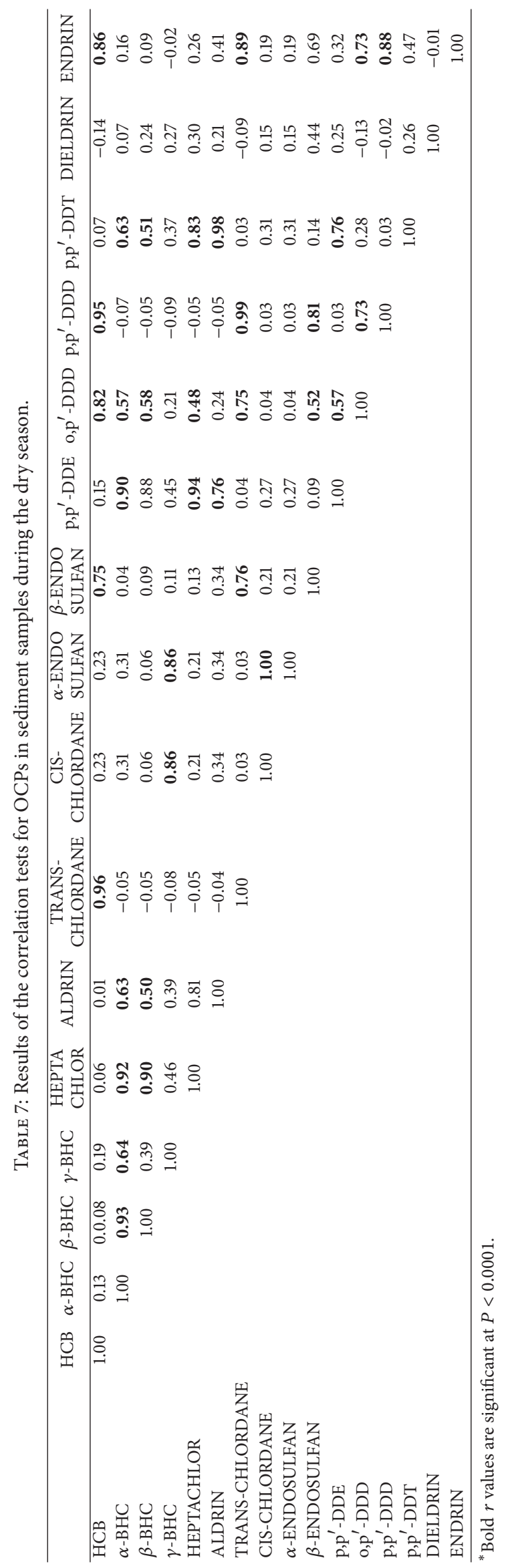


The extraction chamber was depressurized according to the equipment manual. The reduced extract was taken for GC-ECD analysis. Triplicate analyses of the sediment samples from each study site were carried out. The same procedure above was used to extract OCPs from raw sediment samples.

However, standard liquid/liquid extraction method was used to isolate the OCPs from both raw and spiked surface water samples as suggested by Fatoki and Awofolu [24]. The reduced extracts were taken for GC-ECD analyses. Triplicate analyses of the water samples from each study site were done.

\subsection{Gas Chromatographic Analysis of Extracts from Sediment} and Water Samples. One microlitre each of processed sample for GC analysis was injected in turns into the GC-ECD system XL PerkinElmer used in a split less mode and equipped with a ${ }^{63} \mathrm{Ni}$ electron capture detector, column: Zebron $\mathrm{ZB}$ 35 fused silica capillary column $30 \mathrm{~cm} \times 0.25 \mathrm{~mm} \times 0.25 \mu \mathrm{m}$ (film thickness) for analyses. The injector and detector temperatures were maintained at $250^{\circ} \mathrm{C}$ and $300^{\circ} \mathrm{C}$, respectively. The oven temperature was initially maintained at $50^{\circ} \mathrm{C}$ (hold $1 \mathrm{~min}$ ), ramped to $200^{\circ} \mathrm{C}$ at $40^{\circ} \mathrm{C} / \mathrm{min}$ (hold $2 \mathrm{~min}$ ), ramped to $240^{\circ} \mathrm{C}$ at $4^{\circ} \mathrm{C} / \mathrm{min}$ (hold $1 \mathrm{~min}$ ), and finally ramped to $270^{\circ} \mathrm{C}$ at $4^{\circ} \mathrm{C} / \mathrm{min}$ (hold $5 \mathrm{~min}$ ). The carrier gas was $99.999 \%$ nitrogen gas. The carrier gas flow rate was 14 psi for optimum performance. The extraction efficiencies at the different temperature were determined by comparison of the peak areas sample extract with those of the pesticide standard mixture. The response factors were determined according to standard method [25].

The result of the GC-ECD determination of the OC standard mixture and the calculated response factors is presented in Table 1. All the 22 compounds were well resolved and eluted within a reasonable time of less than 30 minutes under the optimized gas chromatograph-electron capture detector (GC-ECD) conditions. The identities of the OCPs in sample extracts were confirmed by spiking and comparing their retention times with those of standards and concentrations were determined by computer calculation making use of both the response factors of the OCPs and the internal standard. The sample clean-up techniques achieved high analyte recoveries of $98.17 \pm 0.03$ to $134.72 \pm 0.02$ for SFE and $84.82 \pm 3.32$ to $102.83 \pm 3.17$ for LLE with RSD of less than $6 \%$ in both cases (Table 1 ).

2.4. Statistical Analysis of the Data. The various data obtained were subjected to New Duncan Multiple Range and Pearson Correlation tests.

\section{Results and Discussion}

The geographical locations of the sampling sites are presented in Table 2. The results of various organochlorine pesticide (OCP) residues in the sediment are as presented in Tables 3 and 4 on seasonal basis. Low concentrations of OCPs were observed for samples taken during the wet season relative to those for the dry season. This is expected because of the dilution at the former season and the fact that the transport and dispersion of pollutants in the aquatic environment is controlled by advection (mass movement) and mixing or diffusion [26]. In the sediment samples, all the analytes except heptachlor, which was not detected $(<0.02 \mu \mathrm{g} / \mathrm{g}$ detection limit), were found at appreciably higher concentration with the following ranges $(\mu \mathrm{g} / \mathrm{g})$ : $\mathrm{HCB}(\mathrm{ND}-25.18 \pm 3.05) ; \alpha-$ $\mathrm{BHC}(\mathrm{ND}-8.07 \pm 3.00) ; \beta-\mathrm{BHC}(\mathrm{ND}-10.91 \pm 6.66)$; $\gamma$-BHC (ND-9.08 \pm 0.02); aldrin (ND-6.55 \pm 0.02); Trans-chlordane (ND-81.32 \pm 7.06$)$; Cis-chlordane $(0.03 \pm$ 0.01-6.99 \pm 0.05); $\alpha$-endosulphan (0.03 \pm 0.01-6.99 \pm 0.02); $\beta$-endosulphan (ND-7.04 \pm 0.02$) ; \mathrm{p}, \mathrm{p}^{\prime}$-DDE $(0.08 \pm$ 0.03-19.04 \pm 1.25$) ; \mathrm{o}, \mathrm{p}^{\prime}-\mathrm{DDD}(\mathrm{ND}-11.15 \pm 1.36) ; \mathrm{p}, \mathrm{p}^{\prime}-$ $\mathrm{DDD}(\mathrm{ND}-57.40 \pm 6.76)$; dieldrin $(0.01 \pm 0.01-7.62 \pm 5.72)$ and endrin $(\mathrm{ND}-21.28 \pm 3.17)$ in almost all the rivers in the dry season (Table 4$)$ than the range $(\mu \mathrm{g} / \mathrm{g})$ in the wet season: $\mathrm{HCB}(\mathrm{ND}-5.55 \pm 0.01) ; \alpha-\mathrm{BHC}(\mathrm{ND}-0.99 \pm 0.03)$; $\beta$-BHC (ND-7.25 \pm 0.01$) ; \gamma$-BHC (ND-5.28 \pm 0.01$)$; heptachlor (ND-1.16 \pm 0.01$)$; aldrin (ND-2.76 \pm 0.02$)$; Transchlordane (ND-4.58 \pm 0.03$)$; Cis-chlordane (ND-2.99 \pm $0.61) ; \alpha$-endosulphan (ND-2.12 \pm 0.19$) ; \beta$-endosulphan $(\mathrm{ND}-1.50 \pm 0.01) ; \mathrm{p}, \mathrm{p}^{\prime}-\mathrm{DDE}(\mathrm{ND}-7.91 \pm 0.04) ; \mathrm{o}, \mathrm{p}^{\prime}-$ $\mathrm{DDD}(\mathrm{ND}-5.18 \pm 0.03) ; \mathrm{p}, \mathrm{p}^{\prime}-\mathrm{DDD}(\mathrm{ND}-10.28 \pm 0.01)$; dieldrin (0.07 $\pm 0.03-8.82 \pm 0.04)$, and endrin (ND-4.43 \pm 0.04 ) (Table 3$)$. The high concentration of p, $\mathrm{p}^{\prime}$-DDT $(17.4 \pm$ $0.01) \mu \mathrm{g} / \mathrm{g}$ in sediments from Agoo River compared to the other DDT metabolites suggests an indication of recent usage of DDT (probably with different trade name) in the study area, more so that at the time of sampling Agoo River, a farmer was spraying a cocoa plantation adjacent to the river. Some of the pesticides detected in the sediments, such as chlordane, heptachlor, DDT, DDE, and endosulfan are known to have endocrine and estrogenic disrupting properties [27], which may greatly impact on the biodiversity of the aquatic ecosystem. The presence of DDT (Table 3) and some of its degradation residues in the matrix can be attributed to their wide usage before their banning [28]. Since they are persistent enough and degrade slowly and easily accumulate in the soil, the transportation of these pesticides both sorbed onto solids and dissolved by the surface water down to the water sources is expected [29]. The persistent half-life of DDT in aquatic environments has been suggested to be approximately 5 years [30], 10-20 years (estimated from studies) in bivalves [31]. As various DDT metabolites persist for a long time in the environment, their gradual degradation occurs under aerobic conditions as DDE and as DDD [32].

Table 5 shows the results of the determination of organochlorine pesticide (OCP) residues in water samples from various rivers on seasonal basis. It has been observed that the concentrations of analytes were very low in the water samples (Table 5) compared to their concentrations in sediment samples (Tables 3 and 4) in both dry and wet season. These results prove that these compounds are not hydrophilic and tend to accumulate in sediment and subsequently in fatty tissue of organisms [33, 34]. Levels of OCPs in the surface water samples from all the rivers in the study area were in trace concentration $(<0.01 \mu \mathrm{g} / \mathrm{L}$ detection limit $)$ for the wet season analyses. However, some elevated levels (Table 5) of $0.34 \mu \mathrm{g} / \mathrm{L}$ of trans-chlordane in Aponmu River, 1.51, 0.11, 0.13 and $0.13 \mu \mathrm{g} / \mathrm{L}$ of Dieldrin, $\mathrm{p}, \mathrm{p}^{\prime}$-DDE, cis-chlordane and $\alpha$ endosulphan, respectively, in Oluwa River, elevated levels 


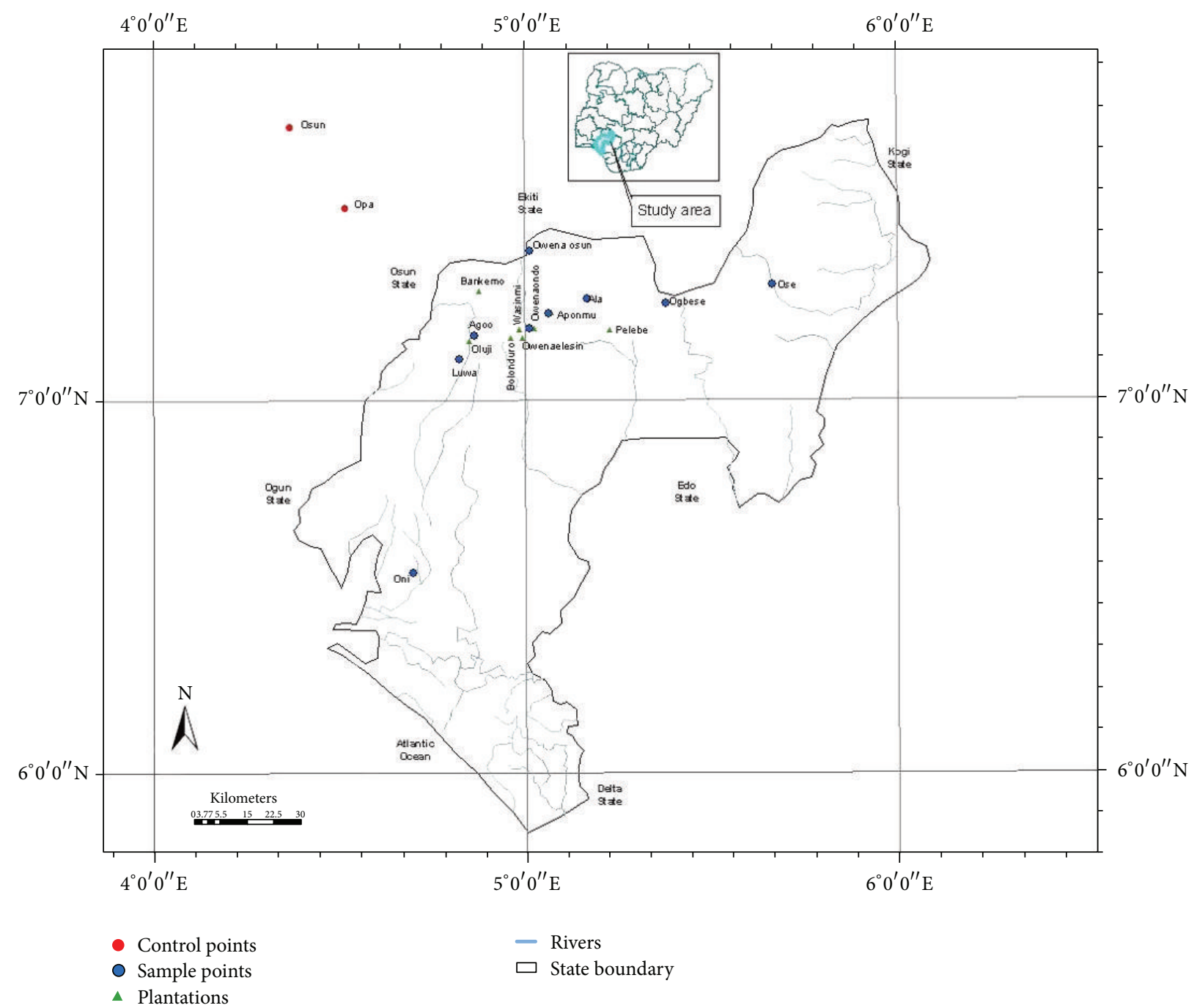

FIGURE 1: Map of the study area showing the geographical locations of sampling points.

of 1.65 and $1.65 \mu \mathrm{g} / \mathrm{L}$ of cis-chlordane and $\alpha$-endosulfan, respectively, in Agoo River gave cause for concern. On the basis of the percentage of the analyte present in each river and the various concentration of each analyte detected, Oluwa River appeared to be the most contaminated. Other compounds were not detected because these compounds are hydrophobic and tend to accumulate in fatty tissue of organisms and sediment.

The result for dry season analyses also indicated that the concentration of most of the analytes is at trace concentration except for trans-chloride $(0.34 \mu \mathrm{g} / \mathrm{L})$, cis-chlordane, and $\alpha$ endosulphan $(0.01 \mu \mathrm{g} / \mathrm{L}$ each $)$, which are detected in Aponmu river and those detected in Oluwa River: cis-chlordane and $\alpha$-endosulphan $(0.13 \mu \mathrm{g} / \mathrm{L}), \mathrm{p}, \mathrm{p}^{\prime}$-DDE $(0.11 \mu \mathrm{g} / \mathrm{L}), \mathrm{o}, \mathrm{p}^{\prime}$-DDD $(0.01 \mu \mathrm{g} / \mathrm{L}), \mathrm{p}, \mathrm{p}^{\prime}-\mathrm{DDT}(0.02 \mu \mathrm{g} / \mathrm{L})$, and dieldrin $(1.51 \mu \mathrm{g} / \mathrm{L})$. The concentration of cis-chlordane and $\alpha$-endosulphan in Agoo River at Ile-Oluji was $1.65 \mu \mathrm{g} / \mathrm{L}$. The amount of aldrin in Owena river at Owena-Ondo was $0.01 \mu \mathrm{g} / \mathrm{L}$.

It was not surprising to detect DDT in water samples of Oluwa River in Ondo State. DDE, which is the most often, recognized metabolite of the DDT, is a very less degradable compound. Another major reason of the presence of DDD in the river, despite the fact that its production is completely banned in the world, is due to the fact that DDD was produced and sold by another name "Rothane" for several years [28]. The results showed that the concentrations of most of the organochlorine compounds analyzed were below the maximum acceptable concentration of $0.1 \mu \mathrm{g} / \mathrm{L}$ value set by the European Union (EU) for the protection of aquatic environment.

3.1. Statistical Analysis. There is no significant difference in the mean concentrations of most of the analytes detected in water and sediment in the results of Duncan multiple range tests (Tables 3, 4, and 5). The correlation tests (Table 6) carried out for sediment for wet season analysis revealed that most of the organochlorine compounds correlate positively $(0.71 \leq$ $r \leq 1.00$ ) with each other at probability level of 0.0001 while $\mathrm{o}$, $\mathrm{p}^{\prime}$-DDD, $\mathrm{p}, \mathrm{p}^{\prime}$-DDD were negatively correlated at probability range of 0.03 to 0.89 . However dieldrin had very low but 
positive correlation within the probability range of 0.0158 to 0.2371 . There were strong correlations (Table 7) between hexachlorobenzene (HCB) and trans-chlordane $(r=0.96)$, $\beta$-endosulphan $(r=0.75)$, o,p-DDD $(r=0.82), \mathrm{p}, \mathrm{p},-\mathrm{DDD}$ $(r=0.95)$, endrin $(r=0.86)$.

\section{Conclusions}

Supercritical fluid extraction (SFE) and liquid/liquid extraction (LLE) have been successfully employed for sample clean-up of sediment and water samples, respectively, in the determination of OCPs in the matrices. The concentrations of contaminants in water samples were very low as compared to concentrations in sediment samples. These results prove that these compounds are hydrophobic and tend to accumulate in sediments and also in fatty tissue of organisms [29]. On the basis of the percentage of the analyte present in each river and the various concentration of each analyte, Oluwa river is the most contaminated. The high concentration of these contaminants is of great concern, especially when the increasing accumulation potential of these compounds in the food chain is considered.

Due to lack of a similar survey for same study area, results could not be compared to determine past situation of the contamination and to estimate time trend. Moreover due to absence of such kind of previous study, numerical decrease factors could not be determined for the region. However, the present study can serve as reference data in the future, if routine monitoring of our environment is embarked upon by all concerned.

\section{Acknowledgments}

The fellowship granted to A. A. Okoya by the Southern and Eastern Africa Network of Analytical Chemists (SEANAC) body which was utilized at the Department of Chemistry, University of Botswana, Gaborone, Botswana is highly acknowledged. The authors are also grateful to the authorities of the Obafemi Awolowo University for releasing her to utilize the grant. This study, however, forms part of the Ph.D. thesis of A. A. Okoya The comments and useful suggestions of the reviewers have considerably improved the quality of the paper.

\section{References}

[1] B. Colin, Environmental Chemistry, W.H. Freeman and Company, 1999.

[2] G. Anitescu and L. L. Tavlarides, "Supercritical extraction of contaminants from soils and sediments," Journal of Supercritical Fluids, vol. 38, no. 2, pp. 167-180, 2006.

[3] A. Eqani, R. N. Malik, A. Alamdar, and H. Faheem, "Status of organochlorine contaminants in the different environmental compartments of Pakistan: a review on occurrence and levels," Bulletin of Environmental Contamination and Toxicology, vol. 88, no. 3, pp. 303-310, 2012.

[4] L. J. Bao, K. A. Maruya, S. A. Snyder, and E. Y. Zeng, "China's water pollution by persistent organic pollutants," Environmental Pollution, vol. 163, pp. 100-108, 2012.
[5] B. Hileman, "Environmental estrogens linked to reproductive abnormalities, cancer," Chemical and Engineering News, vol. 72, no. 5, pp. 19-23, 1994.

[6] D. L. Davis and H. L. Bradlow, "Can environmental estrogens cause breast cancer?” Scientific American, vol. 273, no. 4, pp. 166-172, 1995.

[7] W. R. Kelce, C. R. Stone, S. C. Laws, L. E. Gray, J. A. Kemppainen, and E. M. Wilson, "Persistent DDT metabolite p,p'-DDE is a potent androgen receptor antagonist," Nature, vol. 375, no. 6532, pp. 581-585, 1995.

[8] P. Cocco, A. Blair, P. Congia et al., "Proportional mortality of dichloro-diphenyl-trichloroethane (DDT) workers: a preliminary report," Archives of Environmental Health, vol. 52, no. 4, pp. 299-303, 1997.

[9] D. Pimentel, D. Andow, R. Dyson-Hudson et al., "Environmental and social costs of pesticides: a preliminary assessment," Oikos, vol. 34, no. 2, pp. 126-140, 1980.

[10] UNEP, The Aral Sea: Diagnostic Study for the Development of an Action Plan for the Conservation of the Aral Sea, Nairobi, Kenya, 1993.

[11] S. A. M. A. S. Eqani, R. N. Malik, and A. Mohammad, "The level and distribution of selected organochlorine pesticides in sediments from River Chenab, Pakistan," Environmental Geochemistry and Health, vol. 33, no. 1, pp. 33-47, 2011.

[12] M. Wessel, "Review of the use of fertilizer on cacao in Western Nigeria," Annual Report 79, CRIN, Ibadan, Nigeria, 1966.

[13] L. K. Opeke, Tropical Tree Crops, John Wiley \& Sons, 1st edition, 1982.

[14] N. E. Egbe, E. A. Ayodele, and C. R. Obatolu, Soil and Nutrition of Cocoa, Coffee, Kola, Cashew and Tea. Progress in Tree Research, CRIN, Ibadan, Nigeria, 2nd edition, 1989.

[15] E. Pitarch, C. Medina, T. Portolés, F. J. López, and F. Hernández, "Determination of priority organic micro-pollutants in water by gas chromatography coupled to triple quadrupole mass spectrometry," Analytica Chimica Acta, vol. 583, no. 2, pp. 246258, 2007.

[16] A. Johnson and J. Cowles, "Quality assurance project plan: Washington state surface water monitoring program for pesticides in salmonid habitat: a study for the Washington state," Department of Agriculture Conducted by the Washington State Department of Ecology. Publication Number 03-03-104, http://www.ecy.wa.gov/biblio/0303104.html, 2003.

[17] C. Burke and P. Anderson, "Addendum to the quality assurance project plan for the surface water monitoring program for pesticides in salmonid-bearing streams, addition of the skagitsamish watersheds and extension of program through June 2009," Washington State. Department of Ecology, Olympia, Wash, http://www.ecy.wa.gov/biblio/0303104add.html, 2006.

[18] Z. Tang, Q. Huang, Y. Yang, X. Zhu, and H. Fu, "Organochlorine pesticides in the lower reaches of Yangtze River: occurrence, ecological risk and temporal trends," Ecotoxicology and Environmental Safety, vol. 87, pp. 89-97, 2013.

[19] Federal Environmental Protection Agency (FEPA), Guidelines and Standards for Environmental Pollution Control in Nigeria, 1991.

[20] Federal Republic of Nigeria Official Gazette, Federal Government Press, Lagos, Nigeria. 83, 303-307, 1996.

[21] P. N. Ikemefuna, "Pesticide importation and consumption in Nigeria," in Proceedings of the Pesticide Training Workshop on Environmentally Safe and Effective Control of Pests, UNIFECS/FEPA, Lagos, Nigeria, 1998. 
[22] T. A. Akinnifesi, O. I. Asubiojo, and A. A. Amusan, "Effects of fungicide residues on the physico-chemical characteristics of soils of a major cocoa-producing area of Nigeria," Science of the Total Environment, vol. 366, no. 2-3, pp. 876-879, 2006.

[23] R. Weber, C. Gaus, M. Tysklind et al., "Dioxin- and POPcontaminated sites-contemporary and future relevance and challenges: overview on background, aims and scope of the series," Environmental Science and Pollution Research, vol. 15, no. 5, pp. 363-393, 2008.

[24] O. S. Fatoki and O. R. Awofolu, "Levels of organochlorine pesticide residues in marine-, surface-, ground- and drinking waters from the eastern cape province of South Africa," Journal of Environmental Science and Health B, vol. 39, no. 1, pp. 101-114, 2004.

[25] R. O. Awofolu and O. S. Fatoki, "Persistent organochlorine pesticide residues in freshwater systems and sediments from the Eastern Cape, South Africa," Water SA, vol. 29, no. 3, pp. 323330, 2003.

[26] C. N. Hewitt and R. M. Harrison, "Chapter 1," in Understanding our Environment, R. E. Hester, Ed., Royal Society of Chemistry, London, UK, 1st edition, 1986.

[27] A. M. Soto, K. L. Chung, and C. Sonnenschein, “The pesticides endosulfan, toxaphene, and dieldrin have estrogenic effects on human estrogen-sensitive cells," Environmental Health Perspectives, vol. 102, no. 4, pp. 380-383, 1994.

[28] L. P. Van Dyk, I. H. Wiese, and J. E. Mullen, "Management and determination of pesticide residues in South Africa," Residue Reviews, vol. 82, pp. 37-124, 1982.

[29] A. Aydin and T. Yurdun, "Residues of organochlorine pesticides in water sources of istanbul," Water, Air, and Soil Pollution, vol. 111, no. 1-4, pp. 385-398, 1999.

[30] J. P. Villeneuve, P. P. Carvalho, S. W. Fowler, and C. Cattini, "Levels and trends of PCBs, chlorinated pesticides and petroleum hydrocarbons in mussels from the NW Mediterranean coast: comparison of concentrations in 1973/1974 and 1988/1989," Science of the Total Environment, vol. 237-238, pp. 57-65, 1999.

[31] J. L. Sericano, T. L. Wade, E. L. Atlas, and J. M. Brooks, "Historical perspective on the environmental bioavailability of DDT and its derivatives to Gulf of Mexico oysters," Environmental Science and Technology, vol. 24, no. 10, pp. 1541-1548, 1990.

[32] D. W. Klumpp, H. Huasheng, C. Humphrey, W. Xinhong, and S. Codi, "Toxic contaminants and their biological effects in coastal waters of Xiamen, China. I. Organic pollutants in mussel and fish tissues," Marine Pollution Bulletin, vol. 44, no. 8, pp. 752760, 2002.

[33] Washinton State Pest Monitoring Programme, Pesticides and PCBs in Marine Mussels 1995, Washington State Department of Ecology, 1996.

[34] S. Y. A. Chau and B. K. Afghan, Analysis of Pesticides in Water, Ontario, Canada, 1982. 

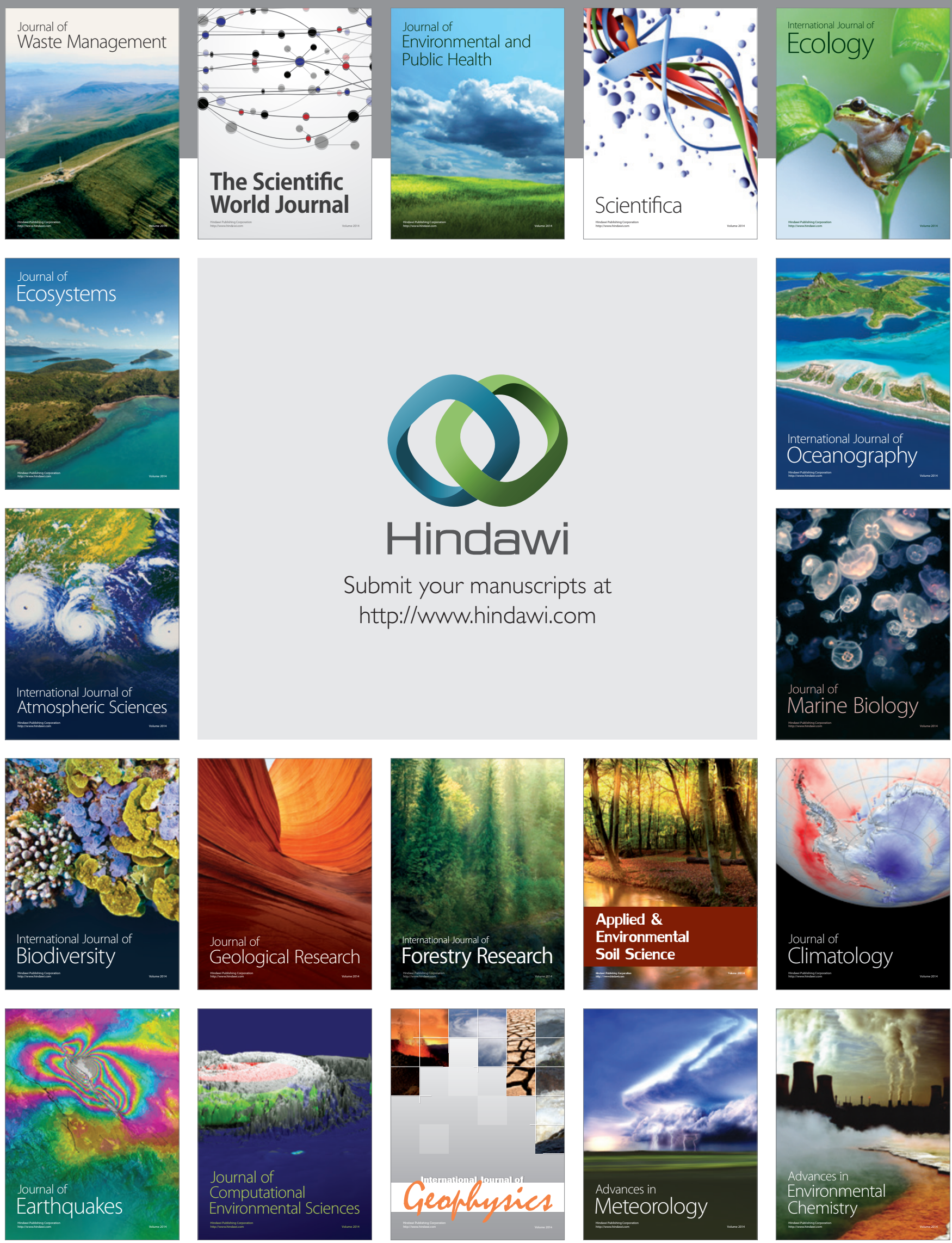